\title{
Generic Strategies and sustainability of Financial Performance of Nepalese Enterprises
}

\author{
Dhundi Bhattarai (Ph D) \\ Lecturer, Nepal Commerce Campus
}

\begin{abstract}
The purpose of this paper is to examine the relationship between firm strategy and sustainability of financial performance of Nepalese Enterprises. The research design adopted in this study consists of descriptive and causal-comparative research designs to deal with the various issues raised in this study. Secondary data has been used for this study which was collected from annual audit report of concerned organization of manufacturing and hotel industrities from fiscal year 2000/01 to 2014/15. Factor analysis, descriptive statistics, correlation analysis, and regression analysis are different statistical tool that has been used for this study. Cost leadership and differentiation strategies has been constructed from selling, general, and administrative expenses divided by sales; sales divided by cost of goods sold; capital expenditure on property, plant, and equipment divided by sales, and net book value of plant and equipment; divided by sales variables through factor analysis. By regressing return on assets of future period against on return on assets, interaction of cost leadership strategy with return on assets, interaction of differentiation strategy with return on assets variables. The analysis shows that the enterprises adopting higher selling, general and administrative expenses in association with higher gross profit margin are pursuing differentiation strategy whereas, higher investment on property, plant and equipment along with their existing higher book value of plant and equipment indicates that they are following cost leadership strategy. When organization is following cost leadership and differentiation strategy both positive effect on sustainability of financial performance of Nepalese enterprises. Out of cost leadership and differentiation strategy, cost leadership is better than differentiation strategy to increase financial performance of Nepalese enterprises.
\end{abstract}

Key Words: Return on assets, Differentiation Strategy, Cost leadership Strategy, financial performance, Nepalese Enterprise

\section{Introduction}

Strategy is a bet which is executed so as to achieve and maintain a high rate of return. Each of the generic strategies involves a fundamentally different route to competitive advantage. To achieve competitive advantage each type of generic strategy comes up with specific target. The cost leadership and differentiation strategy seek competitive advantage in a broad range of industry segments.

With cost leadership, the producer seeks to gain advantage over the whole market by economics of scale and competitive pricing alone. Porter's generic strategy of cost leadership focuses on gaining competitive advantage by having the lowest costs and cost structure in the industry. In order to achieve a low-cost advantage, an organization must have a low-cost leadership mindset, low-cost manufacturing 


\section{Pravaha Journal-2018}

with rapid distribution and replenishment, and a workforce committed to the low-cost strategy. The organization must be willing to discontinue any activity in which they do not have a cost advantage and may outsource activities to other organizations that have a cost advantage. There are many ways to achieve cost leadership such as mass production, mass distribution, economies of scale, technology, product design, input cost, capacity utilization of resources, and access to raw materials. Cost leaders work to have the lowest product or service unit costs; and can survive competition with their lower cost structure. Cost leaders may take a number of cost saving actions, including building efficient scale facilities, tightly controlling overhead and production costs, and monitoring costs to build their relatively standardized products that offer features acceptable to many customers at the lowest competitive price.

The second generic strategy is differentiation and it was defined by Porter (1985), as the ability to provide unique and superior value to the buyer in terms of product quality, special features or after sales service. When using a differentiation strategy, a company focuses effort on providing a unique product or service, setting their offerings separately from competitors. Product differentiation fulfills a customer need and involves uniquely tailoring the product or service to the customer. This strategy allows organizations to charge a premium price to capture market share.

The differentiation strategy is effectively implemented when the business provides unique or superior value to the customer through product quality, features, or after-sale support and service. Firms following a differentiation strategy can charge a higher price for their products based on the product characteristics, the delivery system, the quality of service, or the distribution channels. The quality may be real or perceived, based on fashion, brand name, or image. The differentiation strategy is applied to sophisticated or knowledgeable consumers who are interested in a unique quality product or service and willing to pay a higher price for these non-standardized products.

\section{Review of Literature and Hypothesis development}

Porter's generic strategy framework of differentiation and cost leadership strategy has been shown to be empirically stable with the Miles and Snow (1978) typology of strategy (Shortell \& Zajac, 1990; David, Hwang, Pei \& Reneau, 2002) and is well accepted as internally consistent (Govindarajan, 1988; Miller, 1988). Both strategic frameworks have a single fundamental dimension: the willingness of businesses to alter their products and markets (Hambrick, 1983).

Prospectors aim to create uniqueness for their products and services and create a competitive advantage by being able to charge premium prices for the superiority of their products and services. Defenders, on the other hand, create a competitive advantage as they are able to price their products and services competitively by achieving lower costs. Thus the duality of the prospector/defender framework coincides with the differentiation/cost leadership framework.

Firms pursuing a differentiation strategy attempt to differentiate themselves from their rivals using a variety of sales, marketing and other related activities or product and technological innovations. Differentiation relates to the degree to which a product and its enhancements are perceived as unique. A firm adopting a differentiation strategy can command above-market prices which is possible by the customers' 
perception of the product being special in some way (Berman, Wicks, Kotha \& Jones, 1999). Miller (1986) noted that there are at least two different types of differentiation strategies: those based on product innovation and those based on intensive marketing and image management. The key success factors which contribute to the profitability of a differentiator include creative flair, strong basic research and product engineering (Kotha \& Vadlamani, 1995; Porter, 1980).

A firm can differentiate itself by offering high quality and innovative products with superior design or brand image. It can also apply the technology or customer service, a strategy typically implemented by making investments in costly activities such as extensive research, product design, and marketing. These expenditures, in turn, enable the firm to earn price premiums relative to its competitors. Hambrick (1983), has argued that the main dimension of the cost leadership strategy is efficiency, the degree to which inputs per unit of output are low.

Efficiency can be subdivided into two categories: (a) cost efficiency which measures the degree to which costs per unit of output are low, and (b) asset parsimony which measures the degree to which assets per unit of output are low. Together, cost efficiency and asset parsimony capture a firm's cost leadership orientation.

To the extent that firms following a cost leadership strategy succeed in arranging the minimum amount of operating costs and assets needed to achieve the desired sales, they would be able to improve their financial performance (Hambrick, 1983, Miller, 1987; Porter, 1980). Such firms pay great attention to asset use, employee productivity and discretionary overhead. Their customers buy their products primarily because they are priced below their competitors' equivalent products, an advantage achieved through minimizing costs and assets per unit of output (Hambrick, 1983).

Advantages attained through differentiation are more likely to be sustainable because unique activities or products valued by customers cannot be easily imitated by competitors (Grant, 1991; Porter, 1985). A strategy of differentiation is usually developed around firm-specific and product-specific innovations and marketing effort that may not be easy to imitate quickly. The longer it takes for a competitor to respond to a particular comparative advantage, the greater opportunity there is for a firm to capitalize on the sustained advantages and to create new ones. Barney (2002), has described specific sources such as location, reputation and distribution channel that yield sustainable competitive advantage through product differentiation. On the basis of this literature, this study makes these hypotheses.

H1: Firms pursuing a differentiation strategy are more likely to sustain their financial performance over time than firms pursuing a cost-leadership strategy.

\section{Research methodology}

The research design adopted in this study consists of descriptive and causalcomparative research designs to deal with the various issues raised in this study.

\subsection{Data}

This study focuses the spotlight on cost of goods/cost of service sold and sales revenue out of various elements to measure impact of cost leadership and differentiation strategy to reduce bankruptcy risk. So, this study goes for a limited number of manufacturing and hotel enterprises. The population of this study is eleven 


\section{Pravaha Journal-2018}

listed manufacturing and processing companies which are presently operating and four listed hotels. These are: Bottlers Nepal Ltd.(Balaju), Bottlers Nepal (Terai)Ltd. Raghupati Jute Mills Ltd., Gorakhakali Rubber Udhyog Ltd., Uniliver Nepal Ltd., Nepal Khadya Udhyog Ltd., Fluer Himalayan Ltd., Shree Ram Sugar Mills Ltd, Nepal Bitumin and Barrel Udyog., Himalayan Distillery Ltd., Nepal Lube Oil Ltd,. Soaltee Hotel Ltd., Tara Gaun Regency Hotel Ltd,.Oriental Hotel Ltd., and Yak and Yeti Hotel Ltd. Out of these, Nepal Khadya Udhyog Ltd., Shree Ram Sugars Ltd., Fluer Himalayan Ltd., Raghupati ute Mills Ltd., and Yak and Yeti Hotel has been excluded in the sample due to lack of annual audit report after fiscal year 2011/2012. Remaining seven manufacturing and processing organizations and three hotel organizations has been included in the sample.

To measure impact of generic strategy on sustainability of financial performance of the listed Nepalese enterprises secondary data has been used. These data have been collected from Security Board of Nepal, Nepal Stock Exchange and concerned companies. The data collected from 2000/01 to 2014/15 due to lack of annual audit report of fiscal year of 2015/16 of Gorakhkali Rubber Udhyog Ltd. and Nepal Bitumin and Barrel Udyog Ltd. Data have been converted into five-year moving average.

\subsection{Strategy measures}

To measure strategic positioning of organizations, the following six variables have been typically used to operationalize different strategies.

\section{A. $\quad$ Selling intensity $(S G \& A)$}

It has been calculated as the total sales, general and administrative expenditure divided by net sales (Banker, Mashruwala, and Tripathi, 2006). It reflects a firm's resource allocation for sales and marketing efforts. Firms pursuing a differentiation strategy invest in a variety of advertising, marketing and related activities in order to differentiate themselves from competitors. A higher allocation of resources to SG\&A indicates an effort to build and strengthen the firm's brand and product image. Higher SG\&A thus indicates a greater likelihood that the firm is pursuing a differentiation strategy (David et al, 2002; Berman et al, 1999; Miller and Dess, 1993; Thomas and Litschert, 1991; Hambrick, MacMillan, \& Day, 1982).

\section{B. $\quad$ Gross margin (MARGIN)}

It is measured as the net sales divided by cost of goods sold (Banker, et al., 2006). A firm pursuing a differentiation strategy is likely to create a unique perception of its products and services superior to its competitors, enabling it to command abovemarket prices, and greater profitability (Kotha \& Nair 1995; Nair \& Filer, 2003). Other researchers have used the margin variable to measure cost efficiency (e.g., Hambrick, 1983; Berman et al, 1999).

\section{Capital expenditure (CAPEX)}

It is measured as the capital expenditure on property, plant and equipment divided by net sales (Banker, et al., 2006). It indicates the lack of asset parsimony (Hambrick, 1983; Kotha and Nair, 1995; David et al, 2002). 
D. $\quad$ Capital intensity (CAPINT)

It is asserted as net book value of plant and equipment divided by net sales (Banker, et al., 2006). It indicates the lack of asset parsimony of the business (Hambrick, 1983; Kotha \& Nair, 1995).

\section{Data analysis tools:}

Factor analysis, descriptive statistics, correlation analysis, and regression analysis statistical tools has been used for analyze the data. These are described below.

\section{A. Factor analysis}

Cost leadership and differentiation strategy two variables have been constructed through factor analysis out of four variables which are: SG\&A, MARGIN, CAPEX and CAPINT.

\section{B. Descriptive statistics}

For describing the various characteristics and dimensions of quantitative data, different tools of descriptive statistics are used. Mean, median, minimum value, maximum value and standard deviation were used for analysis of secondary data for this study.

\section{Correlation analysis}

In correlation analysis in this study, different variables such as differentiation strategy, cost leadership strategy, return on assets, and future return on assets on the basis of previous different period on the basis of previous different periods were analyzed.

\section{Regression analysis}

To evaluate the first research hypothesis on the sustainability of financial performance based on the generic strategies followed by organizations, different regression models have been used. Return on assets (ROA) is the measure of a firm financial performance. Achieving a high ROA is an objective of most enterprises. Various studies in the strategic management literature have used ROA as a measure of financial performance of a firm (Bae \& Gargiulo, 2004; Bettis, 1981; Venkataraman \& Ramanujam, 1986; Waddock \& Graves, 1997). Hence, this study has used the following regression equations.

ROAi,t $=\alpha 0+1$ Diffi,t $+\alpha 2$ CLi,t $+\varepsilon i, t \ldots$ (i) (Banker et al, 2006).

Where, ROAi,t is dependent variable. Diffi,t and the CLi,t are independent variables.

ROA $=$ NPAT/TA.

ROAi, $t=$ Return on assets of a firm i in a period $t$

Diffi, $\mathrm{t}=$ Differentiation strategy of a firm $\mathrm{i}$ in a period $\mathrm{t}$

$\mathrm{CLi}, \mathrm{t}=$ Cost leadership strategy of a firm $\mathrm{i}$ in a period $\mathrm{t}$

Strategies are measured by of thirteen firms (ten manufacturing firms and three hotels) of sample Nepalese listed enterprises of five-year moving average from 2000/01 to 2014/15 which are constructed by individual factors scores of CAPEX, SG\&A, CAPINT and MARGIN through factor analysis. 
KMO and Bartlett's Test of four strategic variables are presented in table 1.

Table 1

KMO and Bartlett's test

\begin{tabular}{lcc}
\hline Particulars & \multicolumn{2}{c}{ Results } \\
\hline Kaiser-Meyer-Olkin Measure of Sampling Adequacy. & Approx. Chi-Square & 198.231 \\
Bartlett's Test of Sphericity & Df & 6 \\
& Sig. & 0 \\
\hline
\end{tabular}

The KMO measures the sampling adequacy, which should be greater than 0.5 for a satisfactory factor analysis to proceed (Hutcheson \& Sofroniou, 1999). Table 1 shows that KMO measure is 0.627 and therefore it is satisfactory. Rotated component matrix and communalities of four strategic variables are presented in table 2.

Table 2

Rotated component matrix and communalities

\begin{tabular}{lccc}
\hline & \multicolumn{2}{c}{ Component } & Communalities \\
\hline SG\&A & Diffit & Clit & \\
MARGIN & 0.923 & & .878 \\
CAPEX & 0.891 & & .911 \\
CAPINT & & 0.912 & .864 \\
\hline
\end{tabular}

MARGIN and SG\&A support component 1 and it is denoted by differentiation strategy and remaining two variables support component 2 and it is denoted by cost leadership strategy. (Banker et.al, 2006). With all communalities above 0.6, relatively small samples (less than 100) may be perfectly adequate. With communalities in the 0.5 range, samples between 100 and 200 can be good enough (MacCallum, Widaman, Zhang \& Hong, 1999). Therefore, above value of communalities of each component is sufficient in 110 numbers of observations.

\section{B. Descriptive statistics}

Table 3 offers descriptive statistics on the strategic variables of a firm i in a year $t$ (differentiation and cost leadership), return on assets of a firm $i$ in a year $t$, return on assets of a firm $i$ in future period $t+1$ to $t+5$, cash flow from operation to total assets of a firm $i$ in a year $t$, cash flow from operation to total assets of a firm $i$ in future period $t+1$ to $t+5$, market value per share of a firm $i$ in a year $t$, book value per share of a firm $i$ in a year $t$ and earning per share of a firm $i$ in a year $t$.

Table 3

Descriptive statistics

\begin{tabular}{lccccccc}
\hline & Unit & $\mathrm{N}$ & Mean & Median & Std. Deviation & Minimum & Maximum \\
\hline Diffi, $_{\mathrm{t}}$ & Ratio & 110 & 0 & -0.1921 & 1 & -1.1931 & 2.91324 \\
\hline
\end{tabular}


Pravaha Journal-2018

\begin{tabular}{|c|c|c|c|c|c|c|c|}
\hline & Unit & $\mathrm{N}$ & Mean & Median & Std. Deviation & Minimum & Maximum \\
\hline $\mathrm{CLi}_{\mathrm{t}}$ & " & 110 & 0 & -0.1432 & 1 & -0.7632 & 8.3241 \\
\hline $\mathrm{ROAi}_{\mathrm{t}}$ & $"$ & 110 & 0.00501 & 0.0116 & 0.097 & -0.1711 & 0.37567 \\
\hline $\mathrm{ROAi}_{\mathrm{t}+1}$ & “ & 100 & 0.01029 & 0.01323 & 0.09785 & -0.1639 & 0.37698 \\
\hline $\mathrm{ROAi}_{\mathrm{t}+2}$ & “ & 90 & 0.01432 & 0.01367 & 0.09996 & -0.1324 & 0.37792 \\
\hline $\mathrm{ROAi}_{\mathrm{t}+3}$ & “ & 80 & 0.02211 & 0.01423 & 0.104 & -0.1312 & 0.37693 \\
\hline $\mathrm{ROAi}_{\mathrm{t}+4}$ & “ & 70 & 0.02742 & 0.01301 & 0.10769 & -0.1323 & 0.37842 \\
\hline $\mathrm{ROAi}_{\mathrm{t}+5}$ & “ & 60 & 0.03212 & 0.01521 & 0.1132 & -0.1324 & 0.37617 \\
\hline
\end{tabular}

Table 3 reports the descriptive statistics of all the variables which have been used in this study in different numbers of observations. Mean value and standard deviation of both strategies i.e. cost leadership and differentiation are 0 and 1 respectively. Median value of differentiation strategy and cost leadership strategy is -0.1921 and -0.1432 respectively. Maximum and minimum value of differentiation strategy and cost leadership strategy are $(-1.1931,2.91324)$ and $(-0.7632,8.3241)$ respectively

\section{Correlation analysis}

Table 4 presents the Pearson correlation analyses of the strategic variables of a firm $i$ in a year $t$, return on assets of a firm $i$ in a year $t, t+1$ to $t+5$.

Table 4

Correlation analysis

\begin{tabular}{|c|c|c|c|c|c|c|c|c|}
\hline & Diffi, $_{t}$ & $\mathrm{CLi}_{\mathrm{t}}$ & $\mathrm{ROAi}_{{ }_{\mathrm{t}}}$ & ROAi, $_{t+1}$ & ROAi, $_{t+2}$ & $\mathrm{ROAi}_{\mathrm{t}_{+3}}$ & $\mathrm{ROAi}_{\mathrm{t}+4}$ & ROAi $_{t+5}$ \\
\hline$\overline{\text { Diffi, }}_{t}$ & 1 & & & & & & & \\
\hline $\mathrm{CLi}_{\mathrm{t}}$ & 0 & 1 & & & & & & \\
\hline $\mathrm{ROAi}_{{ }_{\mathrm{t}}}$ & $-0.235^{* *}$ & $0.258^{* * *}$ & 1 & & & & & \\
\hline $\mathrm{ROAi}_{\mathrm{t}+1}$ & $-0.132^{* *}$ & $0.342^{* * *}$ & $.982^{*}$ & 1 & & & & \\
\hline $\mathrm{ROAi}_{\mathrm{t}+2}$ & -0.087 & $0.213^{* * *}$ & $.937^{*}$ & $.983^{*}$ & 1 & & & \\
\hline $\mathrm{ROAi}_{\mathrm{t}+3}$ & $0.006^{* * *}$ & $0.121^{* * *}$ & $.869^{*}$ & $.937^{*}$ & $.984^{*}$ & 1 & & \\
\hline $\mathrm{ROAi}_{\mathrm{t}+4}$ & $0.082^{* * *}$ & $0.123^{* * *}$ & $.781^{*}$ & $.865^{*}$ & $.937^{*}$ & $.983^{*}$ & 1 & \\
\hline $\mathrm{ROAi}_{\mathrm{t}+5}$ & $0.143^{* * *}$ & -0.215 & $.734^{*}$ & $.792^{*}$ & $.863^{*}$ & $.937^{*}$ & $.982^{*}$ & 1 \\
\hline
\end{tabular}

Note: * Significant at 0.01 levels ** Significant at 0.05 levels $\quad * * *$ Significant at 0.10 levels

The correlation analysis gives this study some insights into the relationships between different variables of interest. Differentiation strategy has low degree of negative correlation with future ROAit. Cost leadership strategy has low degree of positive relations $\mathrm{w}$ ith future ROAit.

D. Regression analysis

Impact of cost leadership and differentiation strategy on return on assets on future time period has been measured through five regression model which are given 
below.

$$
\begin{aligned}
& \mathrm{ROAi}_{\mathrm{t}+1}=\mathrm{a}_{0}+\mathrm{B}_{1} \mathrm{ROAi}_{\mathrm{t}}+\mathrm{B}_{2} \mathrm{ROA}_{\mathrm{i}, \mathrm{t}} \mathrm{Diffi}_{\mathrm{t}}+\mathrm{B}_{3} \mathrm{ROA}_{\mathrm{i}, \mathrm{t}} \mathrm{CLi}_{\mathrm{t}_{\mathrm{t}}}+\varepsilon_{\mathrm{i}, \mathrm{t}} \ldots \text { (i) } \\
& \mathrm{ROAi}_{{ }_{\mathrm{t}+2}}=\mathrm{a}_{0}+\beta_{1} \mathrm{ROAi}_{\mathrm{t}_{\mathrm{t}}}+\beta_{2} \mathrm{ROA}_{\mathrm{i}, \mathrm{t}} \mathrm{Diffi}_{\mathrm{t}}+\mathrm{B}_{3} \mathrm{ROA}_{\mathrm{i}, \mathrm{t}} \mathrm{CLi}_{\mathrm{t}}+\varepsilon_{\mathrm{i}, \mathrm{t}} \ldots \ldots \text {. (ii) } \\
& \mathrm{ROAi}_{\mathrm{t}+3}=\mathrm{a}_{0}+\mathrm{B}_{1} \mathrm{ROAi}_{\mathrm{t}}+\mathrm{B}_{2} \mathrm{ROA}_{\mathrm{i}, \mathrm{t}} \text { Diffi, }_{\mathrm{t}}+\mathrm{B}_{3} \mathrm{ROA}_{\mathrm{i}, \mathrm{t}} \mathrm{CLi},{ }_{\mathrm{t}}+\varepsilon_{\mathrm{i}, \mathrm{t}} \ldots \text { (iii) } \\
& \mathrm{ROAi}_{\mathrm{t}+4}=\mathrm{a}_{0}+\mathrm{B}_{1} \mathrm{ROAi}_{\mathrm{t}}+\mathrm{B}_{2} \mathrm{ROA}_{\mathrm{i}, \mathrm{t}} \text { Diffi, }_{\mathrm{t}}+\mathrm{B}_{3} \mathrm{ROA}_{\mathrm{i}, \mathrm{t}} \mathrm{CLi}_{\mathrm{t}}+\varepsilon_{\mathrm{i}, \mathrm{t}} \ldots \text { (iv) } \\
& \mathrm{ROAi}_{\mathrm{t}+5}=\mathrm{a}_{0}+\mathrm{B}_{1} \mathrm{ROAi}_{\mathrm{t}}+\mathrm{B}_{2} \mathrm{ROA}_{\mathrm{i}, \mathrm{t}} \mathrm{Diff}_{\mathrm{t}_{\mathrm{t}}}+\mathrm{B}_{3} \mathrm{ROA}_{\mathrm{i}, \mathrm{t}} \mathrm{CLi},{ }_{\mathrm{t}}+\varepsilon_{\mathrm{i}, \mathrm{t}} \ldots \text { (v) }
\end{aligned}
$$

Out of its only four regressions model only fulfill regression assumptions. Regression model (V) has not fulfilled regression assumption due to multicollinearity problem. The regression result of return on assets from period $t+1$ to $t+4$ on return on assets, interaction of return on assets with differentiation strategy and interaction of return on assets with cost leadership strategy variables are expressed by the abover regression models.

Where, $\mathrm{ROA}_{\mathrm{i}, \mathrm{t}}=$ Return on assets of selected enterprises of five-year moving average of fiscal year from $2000 / 01$ to $2014 / 15$ i.e. 11 period. $\mathrm{ROA}_{\mathrm{i}, \mathrm{t}}$ Diffi, $_{\mathrm{t}}=$ interaction of differentiation strategy with return on assets with respective periods of selected enterprises, $\mathrm{ROA}_{\mathrm{i}, \mathrm{t}} \mathrm{CLi}{ }_{\mathrm{t}}=$ interaction of cost leadership strategy with return on assets of respective periods of selected enterprises, $a_{0}=$ constant value, $B_{1}, B_{2}, B_{3}$ are slopes of independent variables and cit... is error term. $\mathrm{ROA}_{\mathrm{i}, \mathrm{t}+1}$ to $\mathrm{ROA}_{\mathrm{i}, \mathrm{t}+4}=$ Return on Assets of selected enterprises in period $t+1$ to $t+4$.

Glejser test has been used for detecting the problem of heteroscedasticity before dependent variable is regressed on independent variables and it exists in all regression models. Dependent and all independent variables have been divided by unstandardized predicted variables of respective model to minimize heteroscedasticity problem. The computed values of five regression equations of the selected enterprises are presented in table 5 .

Of the regression results from multiple regression first, the explanatory power of the model is reasonably high given as the $\mathrm{R}^{2}$ explains 81.1 percent area. The F-ratio is 121.361 is significant at 1 percent LOS. The value of DW 1.945 indicates that there is no autocorrelation problem. The coefficient value of ROAit means that other variables keeping constant one unit (ratio) increases in ROA of $t+1$ will increase by 1.115 units (ratio) in ROA and it is statistically significant at 5 percent LOS.

Similarly, keeping other variables constant, one unit (ratio) increases in interaction of cost leadership strategy with ROA will increase by 0.789 units (ratio) in $\mathrm{ROA}_{\mathrm{it}+1}$ at 1 percent LOS. When one unit (ratio) increases in interaction of differentiation strategy with ROA will increase by 0.463 units (ratio) in $\mathrm{ROA}_{\mathrm{i}, \mathrm{t}+1}$ by keeping other variables constant and it is statistically significant at 10 percent LOS. Value of VIF of independent variables is less than 10. Hence, all independent variables indicate that there is no multicollinearity problem i.e. there is no correlation between three independent variables. Regression model one has approved that both cost leadership and differentiation strategy are beneficial to increase return on assets but cost leadership strategy is better than differentiation strategy to increase return on assets in future time period. So, this model just opposite with hypothesis one.

Table 5

Regression result of return on assets in period t+1 to 4 on return on assets, interactions of 
Pravaha Journal-2018

differentiation strategy and cost leadership strategy with return on assets of respective years

\begin{tabular}{|c|c|c|c|c|}
\hline Variables & Model I & Model II & Model III & Model IV \\
\hline \multicolumn{5}{|l|}{ Constant } \\
\hline Coefficient & $0.31^{* * *}$ & $1.531^{*}$ & $2.364^{*}$ & $1.421^{*}$ \\
\hline S.E. & 0.421 & 0.323 & 0.277 & 0.323 \\
\hline $\mathrm{T}$ Value & 3.342 & 4.652 & 6.393 & 4.105 \\
\hline \multicolumn{5}{|l|}{$\mathrm{ROA}_{\mathrm{it}}$} \\
\hline Coefficient & $1.115^{* *}$ & $0.028^{* *}$ & $-2.312^{*}$ & $-1.111^{*}$ \\
\hline S.E. & 0.112 & 0.113 & 0.112 & 0.213 \\
\hline T Value & 5.324 & 4.212 & -7.613 & -3.342 \\
\hline VIF & 3.12 & 3.235 & 9.321 & 9.382 \\
\hline \multicolumn{5}{|l|}{$\mathrm{ROA}_{\mathrm{it}} \mathrm{Diff}_{\mathrm{it}}$} \\
\hline Coefficient & $0.463^{* * *}$ & $0.318^{*}$ & $.135^{*}$ & $0.392^{* * *}$ \\
\hline S.E. & 0.113 & 0.031 & 0.121 & 0.242 \\
\hline T Value & 6.314 & 4.344 & 3.126 & 2.345 \\
\hline VIF & 3.231 & 1.697 & 9.081 & 8.862 \\
\hline \multicolumn{5}{|l|}{$\mathrm{ROA}_{i t} \mathrm{CL}_{\mathrm{it}}$} \\
\hline Coefficient & $0.789^{*}$ & $0.462^{* *}$ & $0.313^{*}$ & $0.485^{*}$ \\
\hline S.E. & 0.171 & 0.323 & 0.159 & 0.164 \\
\hline $\mathrm{T}$ Value & 6.61 & 2.31 & 4.162 & 3.532 \\
\hline VIF & 1.213 & 3.213 & 1.895 & 2.135 \\
\hline $\mathrm{R}$ square & 0.811 & 0.521 & 0.541 & 0.589 \\
\hline F value & $121.361^{*}$ & $115.312^{*}$ & $116.997^{*}$ & $118.494^{*}$ \\
\hline D.W. & 1.945 & 2.17 & 1.932 & 1.981 \\
\hline Number of observation & 100 & 90 & 80 & 70 \\
\hline
\end{tabular}

This table 5 presents that F-ratio is 115.312 of regression model second. It is statistically significant at 1 percent LOS. Value of DW is 2.17 and it has been mentioned that there is neither positive nor negative auto correlation. Value of VIF less than 10 of all independent variables indicates that there is no relationship between all independent variables.

Coefficient value of both strategies i.e. differentiation and cost leadership is statistically significant at 1 percent and 5 percent LOS respectively. In a nutshell, this model explains 52.1 percent of total variation. Coefficient value of independent variable interaction of differentiation strategy with ROA and interaction of cost leadership strategy with ROA is positive at different LOS. Hence, the result is dissimilar with hypothesis one.

Coefficient value of regression model third dependent and all three independent variables are statistically significant at 1 percent LOS. F-value is also statistically significant at 1 percent and DW shows that there is no positive and negative auto correlation. All value of VIF of independent variable is less than 10 and it is approved that there is no multicollinearity problem. This model has explained 54.1 percent area. Coefficient value of two independent variables which are interaction of differentiation strategy with ROA and interaction of cost leadership strategy with ROA is positive. Coefficient value of interaction of differentiation strategy with ROA is less than 
interaction of cost leadership strategy. Therefore, result of this model is disimilar with prior expectation.

Coefficient value of interaction of differentiation strategy with ROA and interaction of cost leadership strategy with ROA is positive and statistically significant at 10 percent LOS and 1 percent LOS respectively of regression model four. F-value is significant at 1 percent level. It is predicted regression model. VIF is less than 10 . Value of DW is approved that there is no auto correlation problem in this model. Coefficient value of interaction of differentiation strategy with ROA is less than interaction of cost leadership strategy with ROA at different LOS. This model accounts for 58.9 percent area. Hence, result is just opposite with hypothesis one.

\section{Conclusion}

The enterprises adopting higher selling, general and administrative expenses in association with higher gross profit margin indicates that firms are pursuing differentiation strategy whereas, higher investment on property, plant and equipment along with their existing value indicates that firms are following cost leadership strategy. Cost leadership and differentiation both strategies have played positive significant role to increase sustainability of financial. Performance of Nepalese enterprises . Out of its, cost leadership strategy is better than differentiation strategy to increase financial performance of Nepalese enterprises.

\section{REFERENCES}

Bae, J.H., \& M. Gargiulo (2004). Partner substitutability, alliance network structure and firm profitability in the telecommunications industry. Academy of Management Journal, 47(6), 843-859.

Banker, R. D., Mashruwala, R., \& Tripathy, A. (2006). Generic strategies and sustainability of financial performance. Strategic Management Journal, 12(1), 33-46.

Barney, J. B. (2002). Gaining and sustaining competitive advantage. Prentice-Hall, Englewood Cliffs, NJ.

Berman, S. L., Wicks, A. C., Kotha, S., \& Jones, T. M. (1999). Does stakeholder orientation matter? The relationship between stakeholder management models. Academy of Management Journal, 42(29), 488-506.

Bettis, R.A. (1981). Performance differences in related and unrelated diversified firms. Strategic Management Journal. 2(4), 379-393.

David, J. S., Hwang, Y., Pei, B. K., \& Reneau, W. (2002). The performance effects of congruence between product competitive strategies and purchasing management design. Management Science, $48,866-886$.

Govindarajan, V. (1988). A contingency approach to strategy implementation the business unit level: Integrating administrative mechanisms with strategy. Academy of management Journal, 31(4), 828-853.

Grant, R.M. (1991). The resource-based theory of competitive advantage: Implications for strategy formulation. California Management Review, 33-43.

Hambrick, D.C. (1983). Some tests of the effectiveness and functional attributes of miles and snow's strategic types. Academy of Management Journal, 26(1), 5-26.

Hambrick, D.C., MacMillan, I. C., \& Day, D. I. (1982). Strategic attributes and performance in the four cells of the BCG matrix - A PIMS-based analysis of industrial product business. Academy of 
Management Journal, 25, 510-531.

Hutcheson, G. \& Sofroniou, N. (1999). The multivariate Social Scientist. London; Sage.

Kotha, S., \& Nair, A. (1995). Strategy and environment as determinants of performance: Evidence from the Japanese machine tool industry. Strategic Management Journal.,16(7), 497-518.

Kotha, S., \& Vadlamani L.B. (1995). Assessing generic strategies: An empirical investigation of two competing typologies in discrete manufacturing industries. Strategic Management Journal,16(1), 75-83.

MacCallum, R.C., Widaman, K.F., Zhang, S. \& Hong, S. (1999). Sample size in factor analysis. Psychological Methods, 4(1), 84-99.

Miles, R.E., \& Snow, C.C. (1978). Organizational strategy, structure, and process, McGraw-Hill, New York, NY.

Miller, A., \& Dess, G.G. (1993). Assessing Porter's (1980) model in terms of its generalizability, accuracy and simplicity. Journal of Management Studie, 30(4), 553-585.

Miller, D. (1986). Configurations of strategy and structure: Towards a synthesis. Strategic Management Journal, 7(3), 233-49.

Miller, D. (1987). The structural and environmental correlates of business strategy. Strategic Management Journal, 8(1), 55-76.

Miller, D. (1988). Relating Porter's business strategies to environment and structure: Analysis and performance implications. The Academy of Management Journal, 31(2), 280-308.

Nair, A. \& Filer, L. (2003). Cointegration of firm strategies within groups: A long-run analysis of firm behavior in the Japanese steel industry. Strategic Management Journal, 24, 145-159.

Porter, M.E. (1980). Competitive Strategy, Free Press, New York, NY.

Porter, M.E. (1985). Competitive advantage: Creating and sustaining superior performance. Free Press, New York, NY.

Shortell, S.M., \& Zajac, E.J. (1990). Perceptual and archival measures of Miles and Snow's strategic types: A comprehensive assessment of reliability and validity. The Academy of Management Journal, 33(4), 817-832.

Thomas, A., Litschert,R., \& Ramaswamy, K. (1991). The performance impact of strategy-manager coalignment: An empirical examination. Strategic Management Journal, 12 (October), 509522.

Venkataraman, N., \& V. Ramanujam. (1986). Measurement of business performance in strategy research: Towards a verbal and statistical correspondence. Academy of Management Review. 11, 801-814.

Waddock, S.A., \& S. Graves. (1997). The corporate social performance-financial performance link. Strategic Management Journal. 18, 303-317. 